\title{
On the date of the death of Constantine the son of Irene.
}

The following note is intended to correct an error which has come to be commonly accepted on this subject. Schlosser ${ }^{1}$ ) asserted on the authority of a passage in Theophanes Continuatus that in the time of Michael II Constantine had only recently died; and later writers have been content to follow Schlosser without further examination, and have even asserted that he lived till after Michael's accession ${ }^{2}$ ), a striking instance of the growth of fiction: no one, so far as I am aware, has shown the statement to be erroneous. Yet, if we look at the passage in the Constantinian writer, which Schlosser cites ${ }^{3}$ ), it is at once clear that it does not say what he supposes it to say. In the first place the reference is not to the time of Michael II at all, but


$\mu \varepsilon \tau \eta \lambda \lambda \alpha \chi \dot{\omega} s$ ' $\nu$ ' does not mean 'he had lately died', but 'he was then dead', and all that the writer states is that Constantine was dead at the time of the rebellion of Thomas against Leo ${ }^{4}$ ), as indeed we might reasonably have inferred even if it had not been expressly stated, since it is not likely that Thomas would personate a living man.5) Constantine was therefore certainly dead before the accession of Michael. There exists however evidence, hitherto, I believe, unnoticed which enablea us to throw beok his death to a yet oarlier time. Theodore the Studite in a letter to the monks of Sakkoudion, written, as is clear,

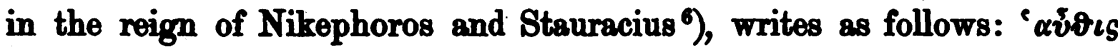



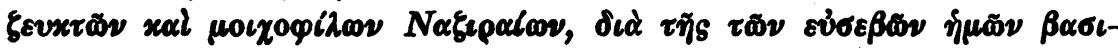

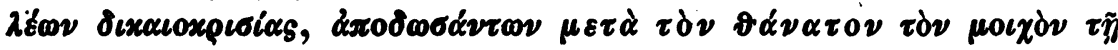

1) Gesch. der bilderstirmenden Kaiser p. $\mathbf{3 3 0}$ note.

2) Bury, History of the later Roman Empire II p. 488; Oman, Byzantine Empire p. 199; Hodgkin, Italy and her Invaders VIII p. 119 note 1.

8) Theoph. cont. 2, 10.

4) So also Genesios (p. 35. 36).

b) Though in 1487 Lambert Simnel personated the living Earl of Warwick. The case of the Norman puppet who personated Michael VII may also be cited.

6) Theod. Stud. Ep. 1, 31. 


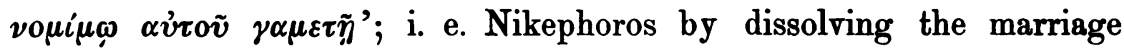
with Theodote restored Constantine after death to his first wife, Mary. ${ }^{1}$ ) After whose death? Not Mary's, for from another letter of Theodore it is clear that she was living after the marriage of her daughter to Michael II. ${ }^{2}$ ) Not Theodote's, for the expression would then be unnatural and illogical. It can therefore only have been Constantine's. Yet again, lower down in the same letter, we find the following

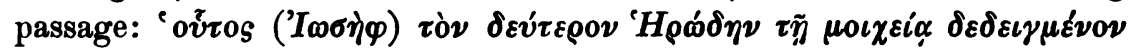

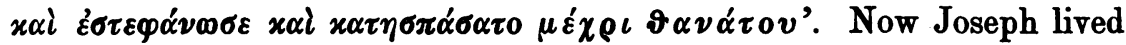
to the time of Michael $\mathrm{I}^{3}$ ); hence here again the death must have been Constantine's. Constantine died therefore not only before the date of this letter $\left.(809-811)^{4}\right)$, but before the dissolution of his marriage by Nikephoros. Now in another letter Theodore implies that the reception of Joseph, which must clearly have been after the dissolution of the marriage ${ }^{5}$ ), took place two years before his own open refusal to communicate with the patriarch ${ }^{6}$ ), which from Theoph. AM 6301 we know to have been at the end of 808 , and it-is fairly certain that since the death of Tarasius (Feb. 18, 806) the Emperor had determined upon the restoration of Joseph. ${ }^{7}$ ) . Constantine therefore died not later than 805 .

The testimony of Theodore is of course conclusive and needs no corroboration; but that he did not live to the time of Leo $V$ might fairly, I think, have been inferred from the statement of Theophanes that the Iconoclasts in 812 put forward the uncles of Constantine as candidates for the Empire, since, if Constantine himself had been alive, one would have expected them to choose him. Blindness clearly did not stand in the way, for his uncles also were blind, and the antiIconoclast policy of his reign had been his mother's: he is said on one occasion to have threatened to destroy the images ${ }^{8}$ ), and would

1) It is not elsewhere stated that Nikephoros did this. As the letter was written while those who refused to communicate with Joseph were being persecuted, the date must be before the accession of Michael.

2) Ep. $2,181$.

3) Vit. I Theod. Stud. 54; vit. II 28.

4) The persecution of the Studites began in Jan. 809 (Theoph. AM 6301).

5) This dissolution cannot have been earlier than Dec. 803 (the coronation of Stauracius).

6) Ep. 1, 25. Joseph was excommunicated 9 years (Ep. 1, 21. 25).

7) The Studites were certainly in opposition from the time of the ordination of Nikephoros (Theoph. AM 6298), and it may be presumed that the Emperor had then abandoned their policy.

8) Narratio de Schismate Studitarum (Migne, Patr. Graec. XCIX p. 1852); cf. Kedr. II p. 26. 
no doubt, if restored, have adopted the policy of those who restored him. Nearer than the years 797-805 it is impossible to fix his death with certainty; but, as Theophanes does not record it, there is some presumption that it occurred before the deposition of Irene, who had reasons for not making the matter public which would not apply to Nikephoros. ${ }^{1}$ ) With this also agrees the statement of Genesios that

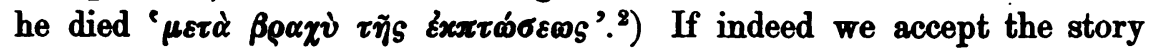
told by George the Monk, Zonaras, and others that he pointed out a secret treasure to Nikephoros, this date must be abandoned; but a story of hidden treasure seems more suited to the Arabian Nights than to history. I may also adduce the statement of George that Thomas personated Constantine at the time of his flight to the Arabs ${ }^{3}$ ), which from the letter of Michael $\mathrm{II}^{4}$ ) we know to have been in the reign of Irene. The participation of Thomas in the rebellion of Vardan rests only on the wild legend told by Genesios and is unknown to Michael.

While I am writing upon this subject, it seems worth while to add a few words upon the exact date of the blinding of Constantine, as to which the narrative of Theophanes is in confusion. After stating that the first attempt to seize the Emperor was on Thurs. Jul. 17, 797 the text goes on to say that he was brought to Constantinople on Saturday the $15^{\text {th }}$ of the same month. Here not only are the dates inconsistent, but Jul: 17, 797 was not a Thursday but a Monday.

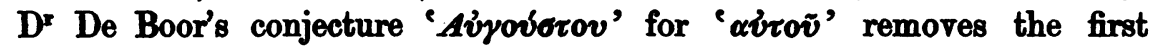
difficulty, but leaves the second untouched and introduces a new one, since Aug. 15 was not a Saturday, but a Tuesday. Also it does not seem likely that the intervening erents occupied a month, and the

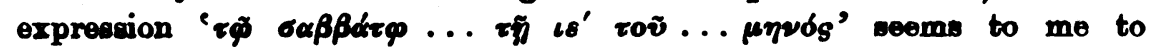
imply that it was the Saturday following the Thursday above mentioned, since otherwise I should expect the day of the week to come after the day of the month and to be without the article (cf. AM 6260).

1) His body was in the tombs of the Emperors (Const. Porph. de Car. Aul. Byz. 2. 42); but it may have been removed there by his son-in-law Michael II.

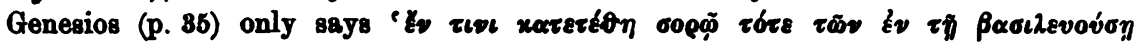

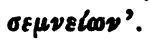

2) Genes. l. c.


Geo. Mon. (ed. Muralt) p. 695. The testimony of Genesios (p. 35) that he lived 25 years among the Arabs before making this claim (an improbable statement in itself) is worth little against that of George. The language of the Latin version of Michael's letter can hardly be trusted on this point.

4) Baronius XIV p. $62 \mathrm{ff}$. 
E. W. Brooks: On the date of the death of Constantine the son of Irene 657

Two explanations are possible. Either retain the date Sat. Jul. $15^{\text {th }}$ and substitute $13^{\text {th }}$ for $17^{\text {th }}$, in which case the statement that the blinding of Constantine was in the same month as that of Nikephoros (AM 6284) is a piece of forgetfulness, or suppose 'Iovdiov' to be a slip for 'A $A$ jov' $\sigma \tau o v$ ' and substitute $19^{\text {th }}$ for $15^{\text {th }} .1$ ) In either case there is no need to alter ' $\alpha \dot{v} \tau o \tilde{v}$ '.

London.

E. W. Brooks.

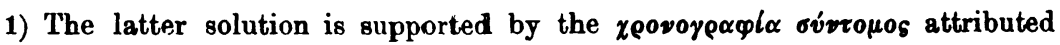
to Nikephoros, which assigns 5 y. $2 \mathrm{~m}$. $12 \mathrm{~d}$. to Irene. The trrms assigned to Constantine and Irene and to Constantine alone, 10 y. 2 m. 2 d. and 6 y. 9 m. 8 d., bring us to Aug. 18. 